Article

\title{
Stevia Eupatoria and Stevia Pilosa Extracts Inhibit the Proliferation and Migration of Prostate Cancer Cells
}

\author{
Elizabeth Martínez-Rojo ${ }^{1}$, Raquel Cariño-Cortés ${ }^{2}{ }^{\mathbb{D}}$, Laura Cristina Berumen ${ }^{1}{ }^{\mathbb{D}}$, \\ Guadalupe García-Alcocer ${ }^{1}$ and Jesica Escobar-Cabrera ${ }^{1, *(D)}$ \\ 1 Unidad de Investigación Genética, Posgrado en Ciencias Químico Biológicas, Facultad de Química, \\ Universidad Autónoma de Querétaro, Centro Universitario, Querétaro 76010, Mexico; \\ elizaro4309@gmail.com (E.M.-R.); lcbsq@yahoo.com (L.C.B.); guadalugar@yahoo.com.mx (G.G.-A.) \\ 2 Centro de Investigación en Biología de la Reproducción del Instituto de Ciencias de la Salud, \\ Universidad Autónoma del Estado de Hidalgo, Pachuca 42082, Hidalgo, Mexico; \\ raquelcarcortes@gmail.com \\ * Correspondence: jeec82@yahoo.com.mx; Tel.: +524-421-921-200 (ext. 5528)
}

Received: 5 January 2020; Accepted: 20 February 2020; Published: 23 February 2020

\begin{abstract}
Background and Objectives: Prostate cancer is the second most harmful disease in men worldwide and the number of cases is increasing. Therefore, new natural agents with anticancer potential should be examined and the response of existing therapeutic drugs must be enhanced. Stevia pilosa and Stevia eupatoria are two species that have been widely used in traditional medicine, but their effectiveness on cancer cells and their interaction with antineoplastic drugs have not been studied. The aim of this study was to evaluate the anticancer activity of Stevia pilosa methanolic root extract (SPME) and Stevia eupatoria methanolic root extract (SEME) and their effect, combined with enzalutamide, on prostate cancer cells. Materials and Methods: The study was conducted on a human fibroblast cell line, and on androgen-dependent (LNCaP) and androgen-independent (PC-3) prostate cancer cell lines. The cell viability was evaluated using a Trypan Blue exclusion test for $48 \mathrm{~h}$, and the migration by a wound-healing assay for 24,48 , and $72 \mathrm{~h}$. Results: The results indicate that SPME and SEME were not cytotoxic at concentrations less than $1000 \mu \mathrm{g} / \mathrm{mL}$ in the human fibroblasts. $S P M E$ and SEME significantly reduced the viability and migration of prostate cancer cells in all concentrations evaluated. The antiproliferative effect of the Stevia extracts was higher in cancer cells than in normal cells. The enzalutamide decreased the cell viability in all concentrations tested $(10-50 \mu \mathrm{M})$. The combination of the Stevia extracts and enzalutamide produced a greater effect on the inhibition of the proliferation and migration of cancer cells than the Stevia extracts alone, but not of the enzalutamide alone. Conclusion: The results indicate that SPME and SEME have an inhibitory effect on the viability and migration of prostate cancer cells and do not interfere with the enzalutamide anticancer effect. The data suggest that Stevia extracts may be a potential source of molecules for cancer treatment.
\end{abstract}

Keywords: Stevia pilosa; Stevia eupatoria; enzalutamide; prostate cancer; proliferation; migration

\section{Introduction}

Prostate cancer $(\mathrm{PCa})$ is one of the most frequent causes of death in men aged over 65 years old around the world [1,2]. PCa development and progression depend on the androgen receptor pathway; the androgen receptor (AR) is a member of the steroid and nuclear hormone receptor superfamily. The main circulating androgen is testosterone, produced in the testes and converted to dihydrotestosterone (DHT) by $5 \alpha$-reductase in the prostate. The AR pathway begins when DHT binds to $\mathrm{AR}$ and induces a conformational change resulting in the dissociation of cytoplasmic chaperones. 
The hormone-bound AR dimerizes and translocates to the nucleus where it binds to DNA and interacts with transcriptional co-regulators to moderate the expression of genes involved in proliferation and survival [3]. Based on the crucial role played by androgens and AR, hormonal therapy is one type of treatment available for prostate cancer [3,4], and the second-generation antiandrogen enzalutamide has been approved for castration-resistant prostate cancer. Enzalutamide inhibits the AR pathway in three steps: by inhibiting receptor binding by DHT, by blocking DHT-AR nuclear translocation, and by interfering with the AR-mediated transcription of genes involved in proliferation and survival. In this way, enzalutamide decreases the proliferation of cancer cells [3,5-7]. Some PCa patients develop castration-resistant prostate cancer and later develop metastases. Few treatments are approved, like enzalutamide, that delay the progression of the illness while maintaining a good quality of life [8]. However, the resistance to therapy and risk of recurrence has led to the search for new effective anticancer compounds, including those from medicinal plants [9]. Stevia is a perennial herbaceous shrub that grows from the Southwest USA to Northern Argentina and is traditionally used as a medicinal plant [10]. Of all the Stevia species that exist, approximately 70 species are native to Mexico, and their anticancer activity has rarely been studied. Stevia pilosa and Stevia eupatoria are used for the treatment of stomach pains as a hypoglycemic agent, and as a diuretic, analgesic, anti-inflammatory, antihypertensive, and mutagenesis protector in cells exposed to alkylating agents [11]. These effects are attributed to their compounds such as flavonoids, sterols, sesquiterpenes, and longipinenes, which possess important biological activities [12]. Some species of Stevia have demonstrated their effect on the antiproliferative activity in cervical, pancreatic, colon, breast, and glioma cancer cells $[10,13,14]$. However, the effects of Stevia pilosa and Stevia eupatoria on the proliferation and migration of cancer cells has not yet been evaluated. Therefore, the aim of this study was to evaluate the effects of Stevia pilosa methanolic root extract (SPME) and Stevia eupatoria methanolic root extract (SEME) alone and in combination with enzalutamide on the cell viability and migration of androgen-dependent (LNCaP) and androgen-independent (PC-3) cell lines.

\section{Materials and Methods}

\subsection{Materials}

The human fibroblasts (HDFn) and LNCaP cell lines were provided by Dr. Claudia Lucia Vargas Requena (Biotechnology Lab, Universidad Autónoma de Ciudad Juárez, Juárez, Chihuahua, México) and Dr. Brenda Anguiano (Instituto de Neurobiología, Universidad Nacional Autónoma de México, Querétaro, Querétaro, México), respectively. The PC-3 cell line was obtained from ATCC (Manassas, VA, USA). The SPME and SEME were provided by Dr. Raquel Cariño Cortés (Toxicology Laboratory, Universidad Autónoma del Estado de Hidalgo, Pachuca de Soto, Hidalgo, México). Dulbecco's modified Eagle's medium (DMEM), Kaighn's modification of Ham's F-12 Medium (F-12K), Roswell Park Memorial Institute (RPMI) 1640 medium, and trypsin were obtained from Corning (Manassas, VA, USA). The enzalutamide was purchased from MedChem Express (Monmouth Junction, NJ, USA). The methodology of this project was approved on 15 December, 2017 by the bioethics committee of Facultad de Química, Universidad Autónoma de Querétaro with the ethical code number CBQ17/101.

\subsection{Cell Culture and Cell Proliferation Assay}

The HDFn, LNCaP, and PC-3 cells were maintained in DMEM, RMPI 1640, and F-12K media, respectively, supplemented with $10 \%$ fetal bovine serum (FBS) and $100 \mathrm{IU} / \mathrm{mL}$ penicillin in a humidified incubator containing $5 \% \mathrm{CO}_{2}$ at $37^{\circ} \mathrm{C}$. For the cell proliferation assay, $5 \times 10^{4}$ cells/well were seeded in a 24-well plate and incubated at $37{ }^{\circ} \mathrm{C}$ and $5 \% \mathrm{CO}_{2}$ for $48 \mathrm{~h}$. After this, the cells were washed with phosphate-buffered saline (PBS) and incubated with different concentrations of SPME or SEME (0, 250, 500, 1000, 2000, 2500 and $3000 \mu \mathrm{g} / \mathrm{mL}$ ) for $48 \mathrm{~h}$. The enzalutamide was evaluated at different concentrations $(0,10,20,30,40$ and $50 \mu \mathrm{M})$ for $48 \mathrm{~h}$. For combinatorial treatments, the cells were incubated with $40 \mu \mathrm{M}$ enzalutamide $+500 \mu \mathrm{g} / \mathrm{mL}$ of extract (SPME or SEME) or $40 \mu \mathrm{M}$ enzalutamide + 
$1000 \mu \mathrm{g} / \mathrm{mL}$ of extract (SPME or SEME) for $48 \mathrm{~h}$. After the treatment, the cells were washed with PBS, trypsinized, and counted with Trypan Blue $0.04 \%$ in a Neubauer chamber. All of the experiments were performed in triplicate, at least.

\subsection{Wound Healing Assay}

The wound-healing assay was conducted to measure the migratory capacity of PCa cells. The PC-3 cells $\left(2 \times 10^{5}\right)$ were seeded in a 6-well plate and grew until they formed a confluent monolayer. The monolayers were scratched with three wounds per well and washed with PBS. Then, for the individual treatments, the cells were treated with different concentrations of SPME or SEME (250, 1000, and $2500 \mu \mathrm{g} / \mathrm{mL}$ ). For the combinatorial treatment, the cells were incubated with $40 \mu \mathrm{M}$ enzalutamide $+1000 \mu \mathrm{g} / \mathrm{mL}$ of SPME or SEME. The wound closure was evaluated at $0,24,48$, and $72 \mathrm{~h}$ after exposure to extracts. The migration rate was calculated as follows: Migration rate $=$ (Average distance between wound (at $0 \mathrm{~h}$ ) —average distance between wound (at $72 \mathrm{~h}$ ))/Average distance between wound (at $0 \mathrm{~h}$ ). We calculated the wound width by measuring the distance between 3 random points within the wound edges.

\subsection{Statistical Analysis}

Data were analyzed with Graph Pad Software Prism 6.0 (San Diego, CA, USA) and expressed as mean \pm standard error of the mean (S.E.M.) of three independent experiments. Data were compared among groups using a one-way analysis of variance (ANOVA) with a Tukey test used for post-hoc comparisons. The statistical significance was set at $P<0.05$.

\section{Results}

\subsection{Effect of Stevia Pilosa and Stevia Eupatoria on the Proliferation of Human Fibroblasts}

To determine whether SPME and SEME have a cytotoxic effect on untransformed cells, the human fibroblasts were treated with both extracts. As a result, the proliferation of treated cells with 250, 500 and $1000 \mu \mathrm{g} / \mathrm{mL}$ did not show a significant difference with respect to the control. The cytotoxicity was observed from the concentration of $2000 \mu \mathrm{g} / \mathrm{mL}$ to decrease the percentage of live cells by $58.6 \%$ with $2000 \mu \mathrm{g} / \mathrm{mL}, 65.7 \%$ with $2500 \mu \mathrm{g} / \mathrm{mL}$, and $73.3 \%$ with $3000 \mu \mathrm{g} / \mathrm{mL}$ of SPME (Figure $1 \mathrm{~A}$ ); and $45.2 \%$ with $2000 \mu \mathrm{g} / \mathrm{mL}, 61.5 \%$ with $2500 \mu \mathrm{g} / \mathrm{mL}$, and 73.1\% with $3000 \mu \mathrm{g} / \mathrm{mL}$ of SEME (Figure 1B).
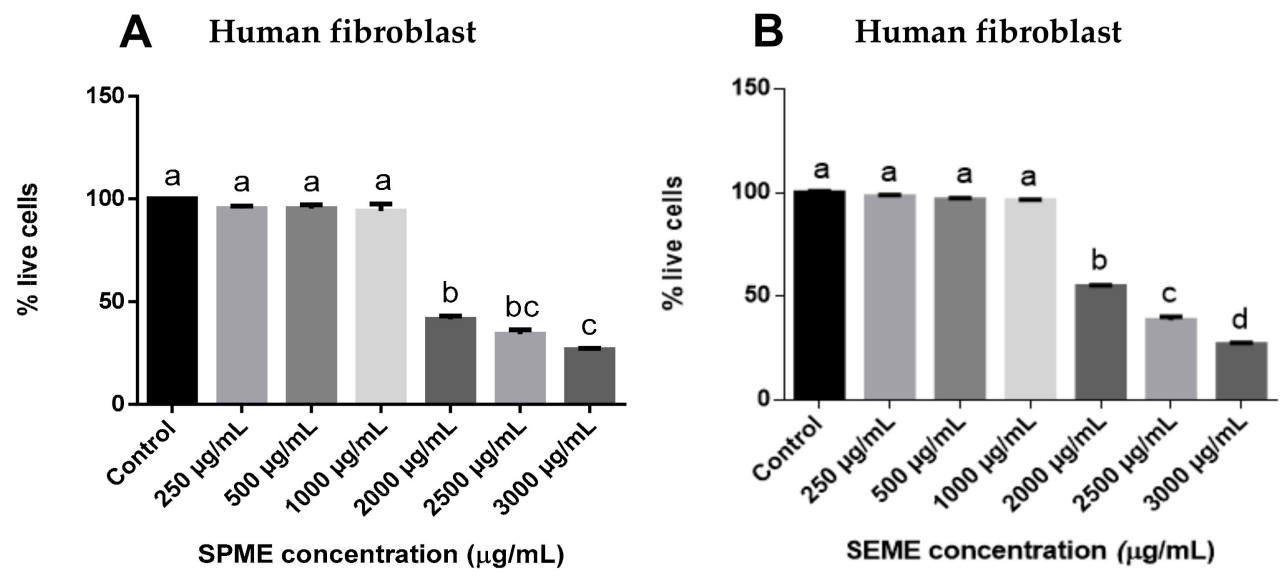

Figure 1. Effect of Stevia extracts on the proliferation of human fibroblasts. Human fibroblasts treated with (A) Stevia pilosa methanolic root extrac (SPME) and (B) Stevia eupatoria methanolic root extrac (SEME). Cells were treated for $48 \mathrm{~h}$. Values are expressed as mean \pm standard error of the mean (S.E.M.) Values with different letters $(\mathrm{a}-\mathrm{d})$ are significantly different $(P<0.05)$. Experiments were performed three times. 


\subsection{Stevia Pilosa and Stevia Eupatoria Inhibited Proliferation of Prostate Cancer Cell Lines}

We treated androgen-dependent cells (LNCaP) and androgen-independent cells (PC-3) with different concentrations of both extracts for $48 \mathrm{~h}$. The concentrations of 250, 500, 1000, 2000, 2500, and $3000 \mu \mathrm{g} / \mathrm{mL}$ of $S P M E$ or SEME inhibited proliferation in a concentration-dependent manner. SPME produced inhibition rates of $13.1 \%, 26.1 \%, 34.8 \%, 52.2 \%, 65.3 \%$, and $69.6 \%$ in LNCaP cells (Figure 2A) and 30.4\%, 30.4\%, 34.7\%, 43.5\%, 56.5\%, and 69.6\% in PC-3 cells, respectively (Figure 2C). SEME also inhibited proliferation, showing inhibition rates of $17.4 \%, 26 \%, 34.7 \%, 47.8 \%, 56.5 \%$, and $69.5 \%$ in LNCaP cells (Figure 2B), and $30.4 \%, 43.5 \%, 47.8 \%, 60.9 \%, 73.9 \%$, and $78.3 \%$ in PC-3 cells, respectively (Figure 2D).

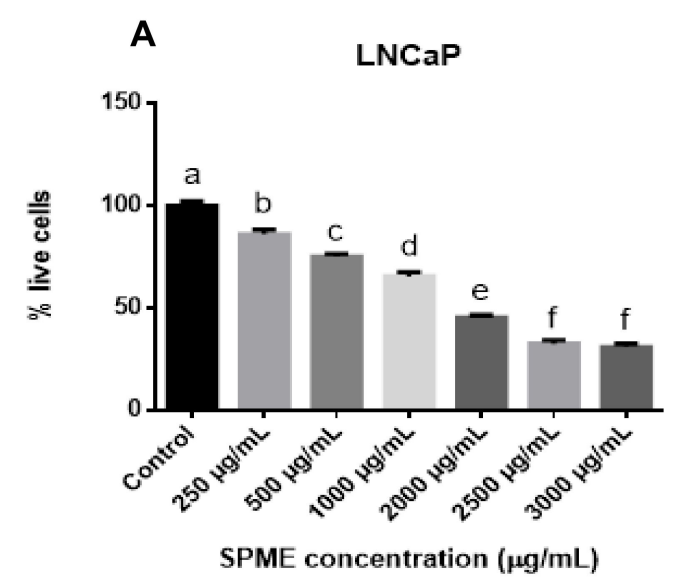

C

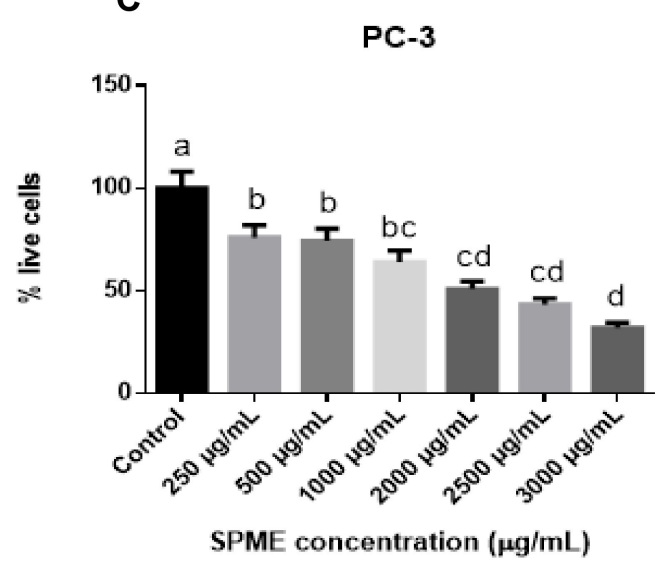

B

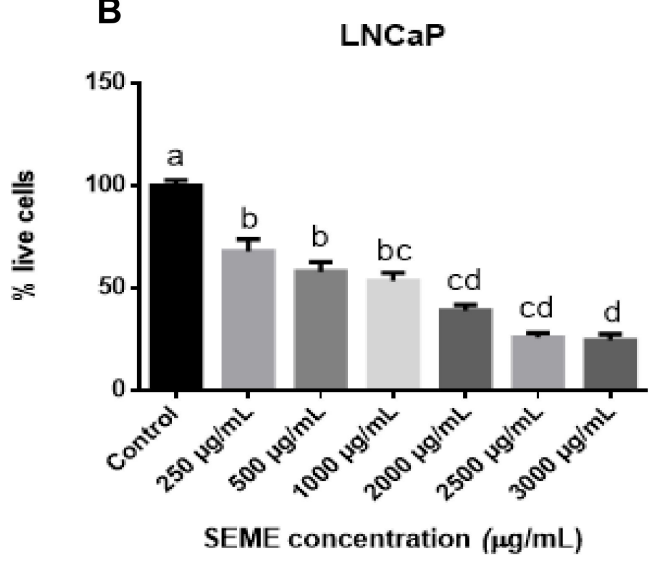

D

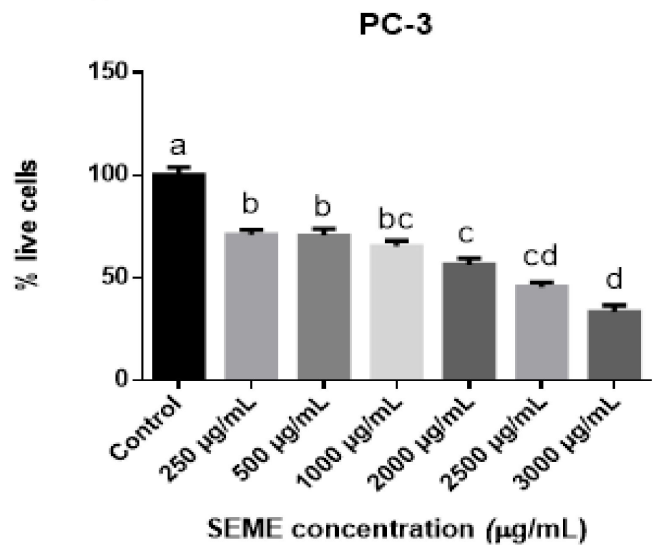

Figure 2. Effect of SPME and SEME on proliferation in prostate cancer cell lines. LNCaP cells treated with (A) SPME and (B) SEME; PC-3 cells treated with (C) SPME and (D) SEME. Cells were treated for $48 \mathrm{~h}$ with the extracts. Values are expressed as mean \pm S.E.M. Values with different letters (a-e) are significantly different $(P<0.05)$. Experiments were performed three times.

\subsection{Effect of the Combinatorial Treatment of Stevia Extracts with Enzalutamide on LNCaP and PC-3 Cell Viability}

We first evaluated the inhibitory effect of enzalutamide in the LNCaP and PC-3 cells, which showed a dose-dependent decrease in viability. Figure 3A shows a decrease at $10 \mu \mathrm{M}$ of $14.4 \%, 20 \mu \mathrm{M}$ of $39.8 \%, 30 \mu \mathrm{M}$ of $69.8 \%, 40 \mu \mathrm{M}$ of $79.6 \%$, and $50 \mu \mathrm{M}$ of $85 \%$ for LNCaP cells, whereas Figure 3B indicates a reduction at $20 \mu \mathrm{M}$ of $14.2 \%, 30 \mu \mathrm{M}$ of $44.3 \%, 40 \mu \mathrm{M}$ of $49.6 \%$, and $50 \mu \mathrm{M}$ of $57.1 \%$ for PC-3 cells. The LNCaP cells showed lower viability than the PC-3 cells treated with enzalutamide. For combinatorial treatment, the cells were incubated with $40 \mu \mathrm{M}$ of enzalutamide $+500 \mu \mathrm{g} / \mathrm{mL}$ of SPME or SEME, and $40 \mu \mathrm{M}$ of enzalutamide $+1000 \mu \mathrm{g} / \mathrm{mL}$ of SPME or SEME. The cells treated 
with the combination of Stevia extracts and enzalutamide and the cells treated with enzalutamide alone showed the same viability; enzalutamide treatment alone reduced viability by $80 \%, 40 \mu \mathrm{M}$ enzalutamide $+500 \mu \mathrm{g} / \mathrm{mL} S P M E$ reduced viability by $76 \%$, and $40 \mu \mathrm{M}$ enzalutamide $+1000 \mu \mathrm{g} / \mathrm{mL}$ SPME reduced viability by $80 \%$ of LNCaP cells (Figure $4 \mathrm{~A}$ ). The cell viability with $40 \mu \mathrm{M}$ enzalutamide $+500 \mu \mathrm{g} / \mathrm{mL}$ SEME was reduced by $77 \%$; for cells treated with $40 \mu \mathrm{M}$ enzalutamide $+1000 \mu \mathrm{g} / \mathrm{mL}$ SEME, viability was reduced by $79 \%$ of LNCaP cells (Figure 4B). A similar effect was observed in the PC-3 cells: enzalutamide reduced viability until $47.5 \%$, whereas combinatorial treatments showed a reduction of $40.1 \%$ with $40 \mu \mathrm{M}$ enzalutamide $+500 \mu \mathrm{g} / \mathrm{mL}$ SPME and $54.8 \%$ with $40 \mu \mathrm{M}$ enzalutamide $+1000 \mu \mathrm{g} / \mathrm{mL}$ SPME (Figure $4 \mathrm{C}$ ). The cell viability was reduced by $51.6 \%$ with $40 \mu \mathrm{M}$ enzalutamide + $500 \mu \mathrm{g} / \mathrm{mL}$ SEME and by $57.2 \%$ with $40 \mu \mathrm{M}$ enzalutamide $+1000 \mu \mathrm{g} / \mathrm{mL}$ SEME (Figure 4D). We found no significant difference between enzalutamide treatment alone and the combinations. The LNCaP cells showed a higher sensitivity to the treatments than the PC-3 cells.
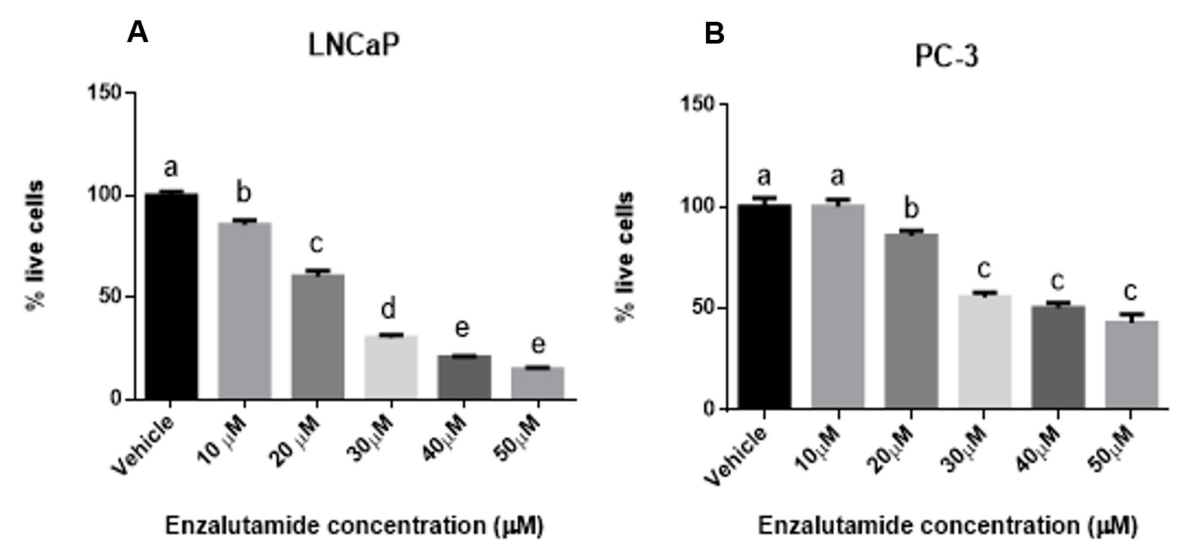

Figure 3. Enzalutamide effect on viability of prostate cancer cells. (A) LNCaP cells and (B) PC-3 cells exposed to enzalutamide for $48 \mathrm{~h}$. Values are expressed as mean \pm S.E.M. Values with different letters $(\mathrm{a}-\mathrm{e})$ are significantly different $(P<0.05)$. Experiments were performed three times. 
A

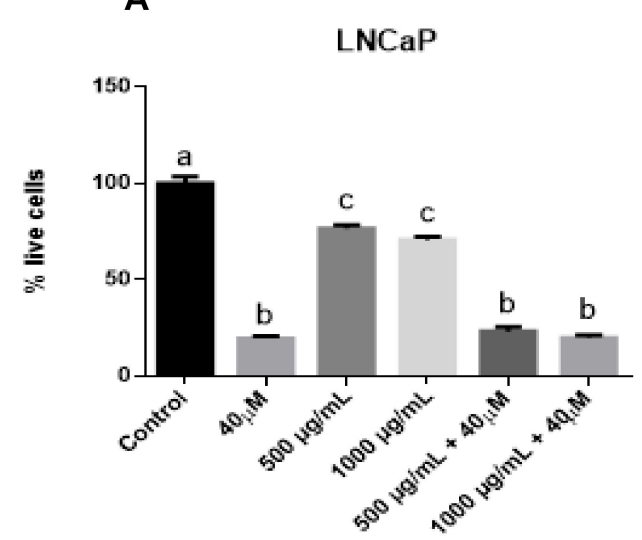

Enzalutamide $(\mu \mathrm{M})$ and SPME $(\mu \mathrm{g} / \mathrm{mL})$ concentration

C

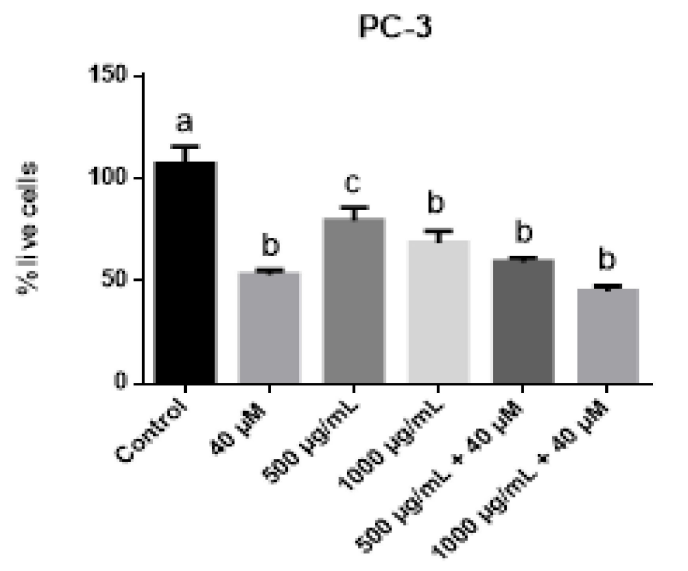

Enzalutamide ( $\mu M)$ y SPME $(\mu g / m L)$ concentratior
B

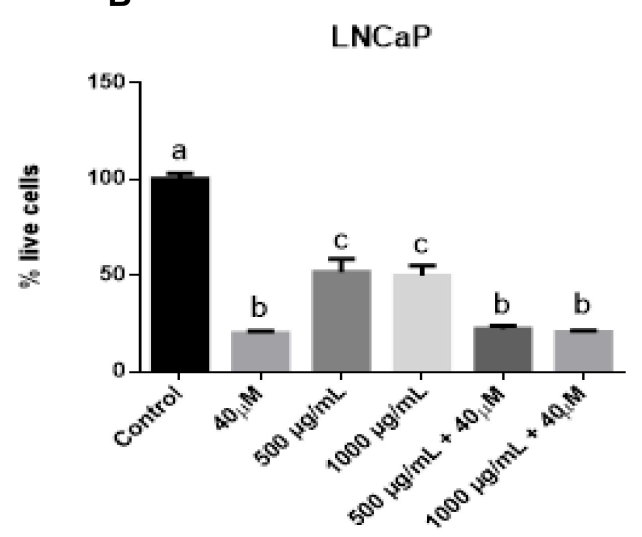

Enzalutamide ( $\mu \mathrm{MM})$ and SEME ( $\mu \mathrm{g} / \mathrm{mL})$ concentration

D

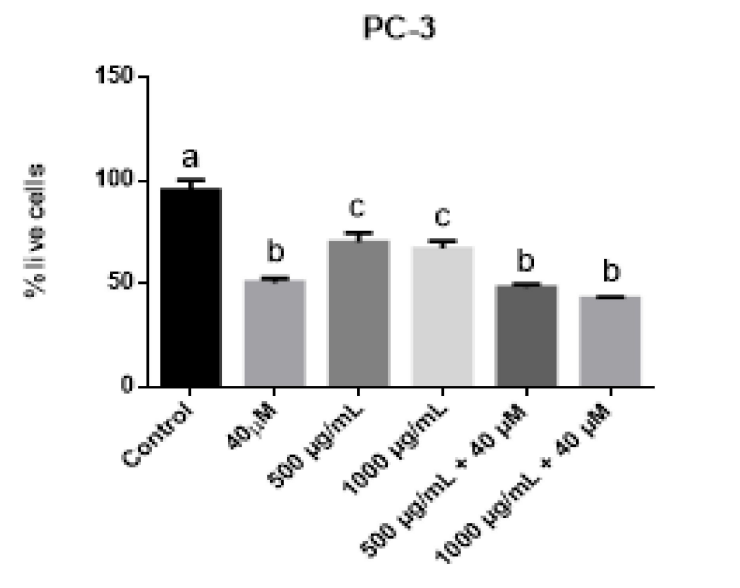

Figure 4. Effect of combinatorial treatment on the proliferation of prostate cancer cells. (A) LNCaP cells treated with enzalutamide and SPME, (B) LNCaP cells treated with enzalutamide and SEME, (C) PC-3 cells treated with enzalutamide and SPME, and (D) PC-3 cells treated with enzalutamide and SEME. Cells were treated with $40 \mu \mathrm{M}$ enzalutamide $+500 \mu \mathrm{g} / \mathrm{mL} S P M E$ or SEME, and $40 \mu \mathrm{M}$ of enzalutamide $+1000 \mu \mathrm{g} / \mathrm{mL}$ of SPME or SEME for $48 \mathrm{~h}$. Values are expressed as mean \pm S.E.M. Values with different letters $(\mathrm{a}-\mathrm{c})$ are significantly different $(P<0.05)$. Experiments were performed three times.

\subsection{Stevia Pilosa and Stevia Eupatoria Inhibited PC-3 Cell Migration}

We used a wound-healing assay to evaluate the effect of SPME and SEME extracts alone on the PC-3 cells. In control cells, the wound closed at $24 \mathrm{~h}$ for both extracts, indicating cell migration under normal conditions; cells treated with $250 \mu \mathrm{g} / \mathrm{mL} S P M E$ closed the wound at $48 \mathrm{~h}$; with $1000 \mu \mathrm{g} / \mathrm{mL}$, the wound closed at $72 \mathrm{~h}$; and with $2500 \mu \mathrm{g} / \mathrm{mL}$, the wound did not close at any time evaluated (Figure 5). The results for SEME showed that wound closure for cells treated with $250 \mu \mathrm{g} / \mathrm{mL}$ occurred at $24 \mathrm{~h}$, cells with $1000 \mu \mathrm{g} / \mathrm{mL}$ treatment showed wound closure at $48 \mathrm{~h}$, and the $2500 \mu \mathrm{g} / \mathrm{mL}$ treatment prevented wound closure at all times evaluated (Figure 6). The migration rate of cells treated with SPME and SEME was calculated. In all concentrations tested, SPME significantly inhibited the migration of the PC-3 cells at $24 \mathrm{~h}$ with a concentration-dependent response. At $48 \mathrm{~h}$ of exposure, only 1000 and $2500 \mu \mathrm{g} / \mathrm{mL}$ displayed an inhibition of migration, and at $72 \mathrm{~h}$, only $2500 \mu \mathrm{g} / \mathrm{mL}$ had an anti-migratory effect. The higher concentration of SPME $(2500 \mu \mathrm{g} / \mathrm{mL})$ inhibited the migration at all times tested, with values of $37 \%$ at $24 \mathrm{~h}, 38 \%$ at $48 \mathrm{~h}$, and $40 \%$ at $72 \mathrm{~h}$ (Figure $7 \mathrm{~A}$ ). SEME significantly inhibited the PC-3 cell migration with 1000 and $2500 \mu \mathrm{g} / \mathrm{mL}$ at 24 and $48 \mathrm{~h}$ of exposure compared to the control, 
and at $72 \mathrm{~h}$, only $2500 \mu \mathrm{g} / \mathrm{mL}$ had an anti-migratory effect. The higher concentration of SEME (2500 $\mu \mathrm{g} / \mathrm{mL}$ ) inhibited the migration at all times tested, with values of $42 \%$ at $24 \mathrm{~h}, 48 \%$ at $48 \mathrm{~h}$, and $54 \%$ at $72 \mathrm{~h}$ (Figure 7B).

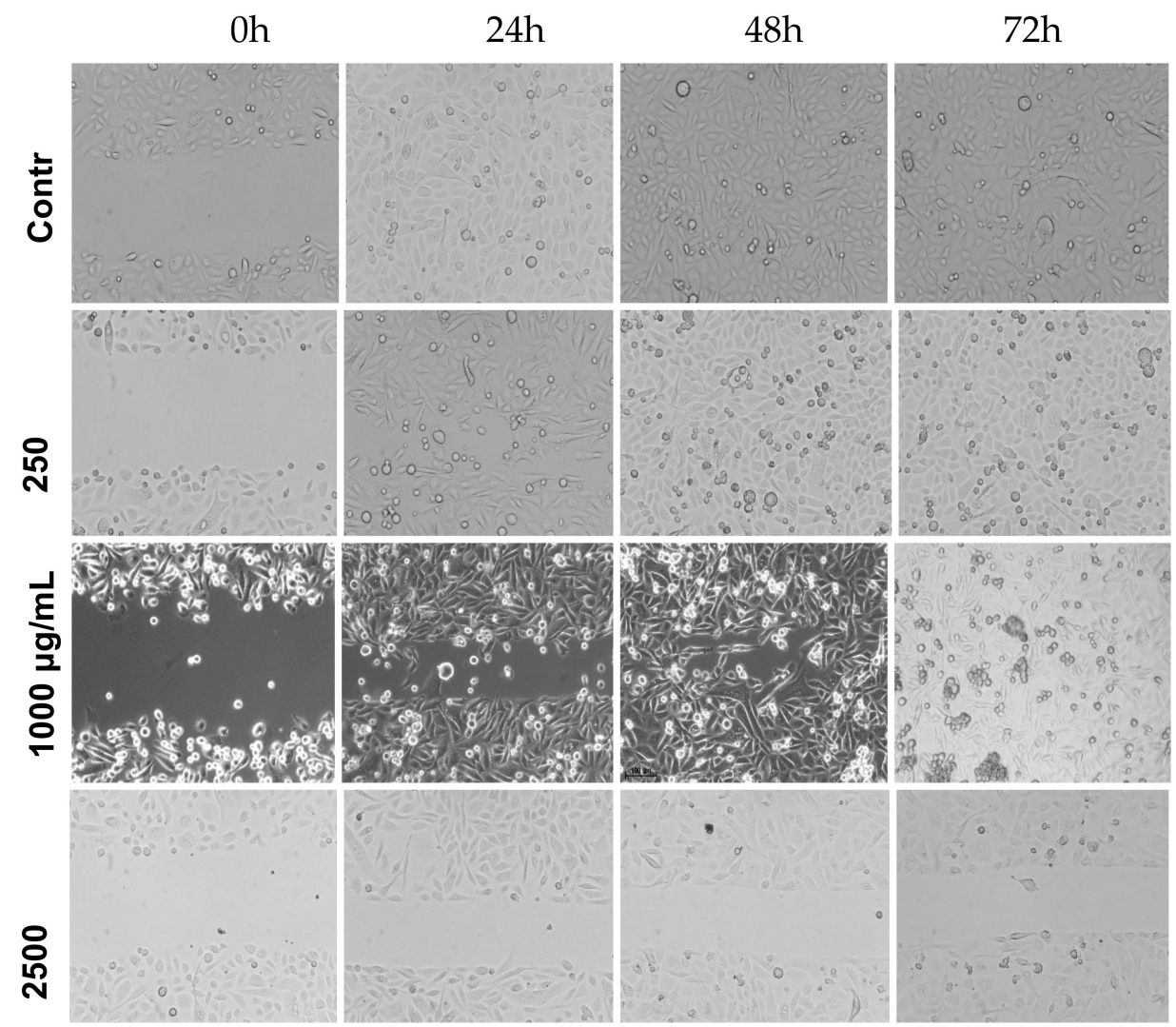

Figure 5. Effect of the Stevia pilosa on PC-3 cell migration. Cells were treated with SPME in different concentrations for 24, 48 and $72 \mathrm{~h}$. Experiments were performed at least three times. 


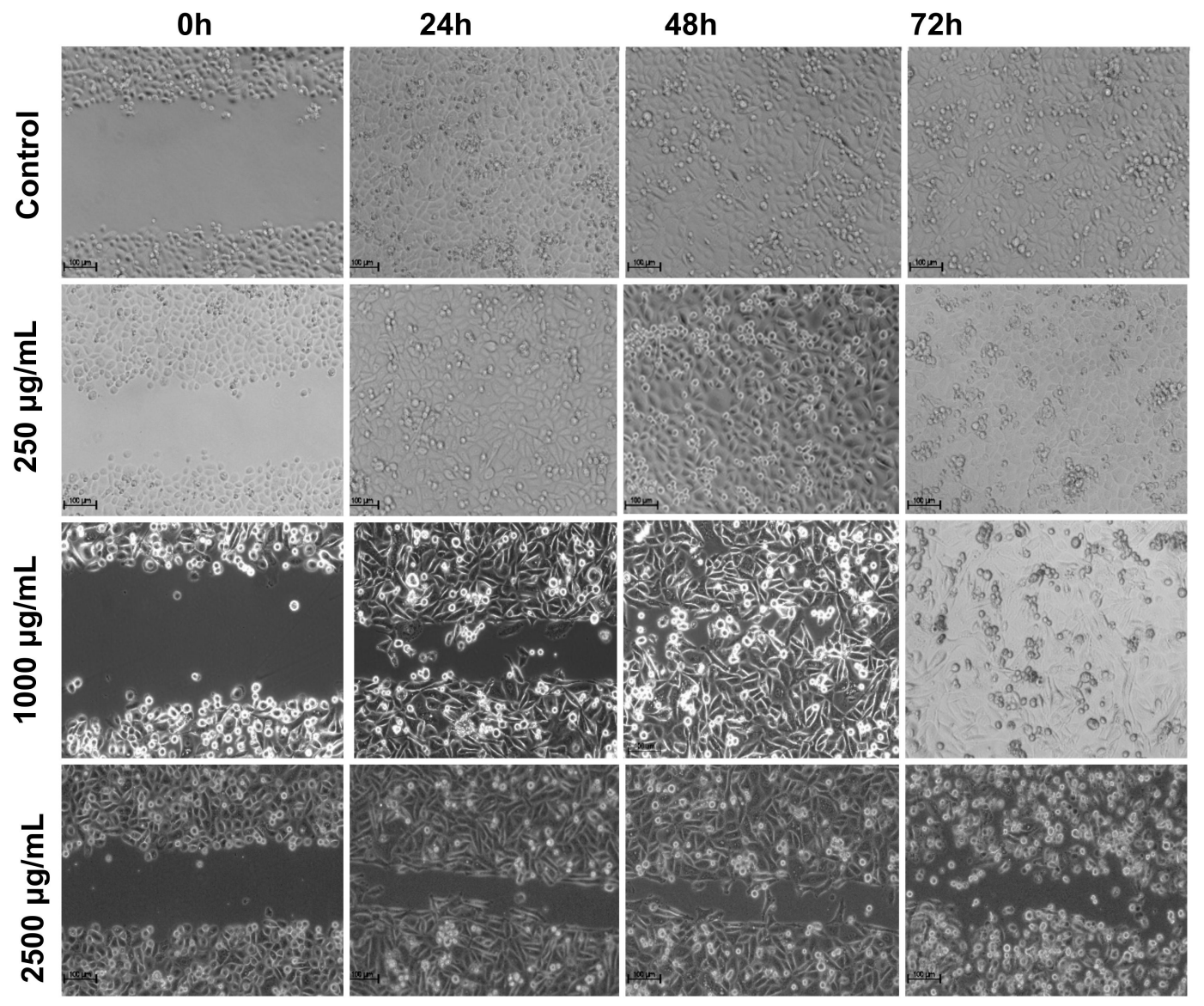

Figure 6. Effect of the Stevia eupatoria on PC-3 cell migration. Cells were treated with SEME in different concentrations for 24, 48, and $72 \mathrm{~h}$. Experiments were performed at least three times.

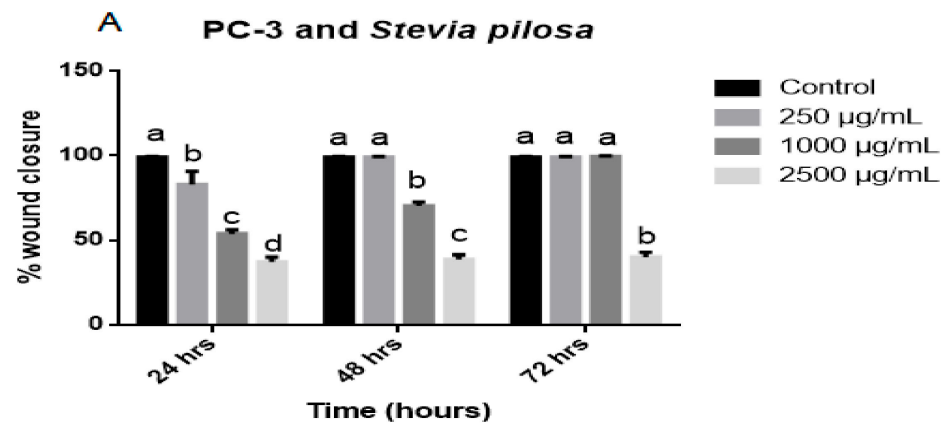

B PC-3 and Stevia eupatoria

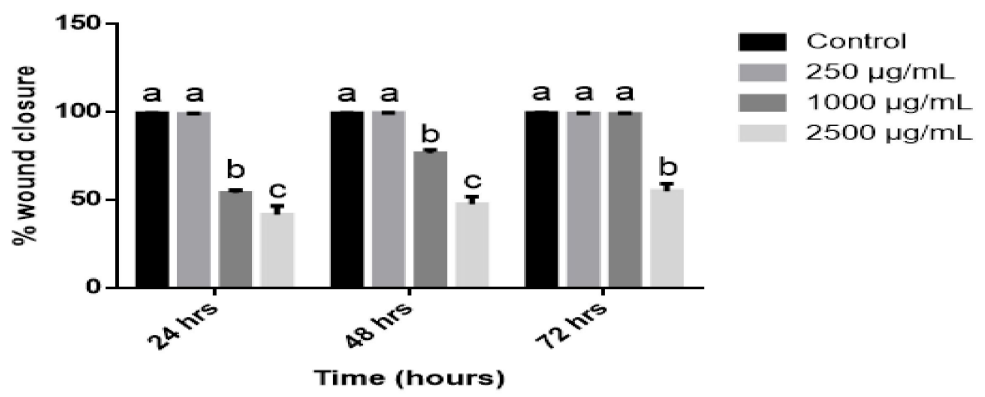

Figure 7. Wound closure rate of PC-3 cells' migration exposed to Stevia extracts. (A) SPME and (B) SEME effects on PC-3 migration. Values are expressed as mean \pm S.E.M. Values with different letters $(a-e)$ are significantly different $(P<0.05)$. Experiments were performed at least three times. 


\subsection{Combinatorial Effect of Stevia Extracts with Enzalutamide on PC-3 Cell Migration}

A wound-healing assay was performed for the PC-3 cells treated with a combination of Stevia extracts and enzalutamide. A total of $1000 \mu \mathrm{g} / \mathrm{mL}$ (the maximum non-cytotoxic concentration in fibroblasts) of the extracts with $40 \mu \mathrm{M}$ of enzalutamide was used. SPME treatment alone showed a migration rate of $54 \%, 70 \%$, and $100 \%$ at 24,48 , and $72 \mathrm{~h}$, respectively. The combination of SPME with enzalutamide inhibited the closing of the scratch at all of the times evaluated, showing inhibition of migration rates of $40 \%, 42 \%$ and $45 \%$ at 24,48 , and $72 \mathrm{~h}$, respectively. The combined treatment significantly increased the inhibition of closure of the wound compared to SPME alone (Figure 8). The treatment with SEME alone produced a migration rate of $54 \%, 77 \%$, and $100 \%$ at 24,48 , and $72 \mathrm{~h}$ of exposure, respectively. The combination of SEME with enzalutamide inhibited the closing of the scratch at all of the times evaluated, and the migration rates were $42 \%, 54 \%$, and $56 \%$ at 24,48 , and $72 \mathrm{~h}$, respectively. The combined treatment of SEME with enzalutamide significantly increased the inhibition of the closure of the wound compared to SEME alone (Figure 9).

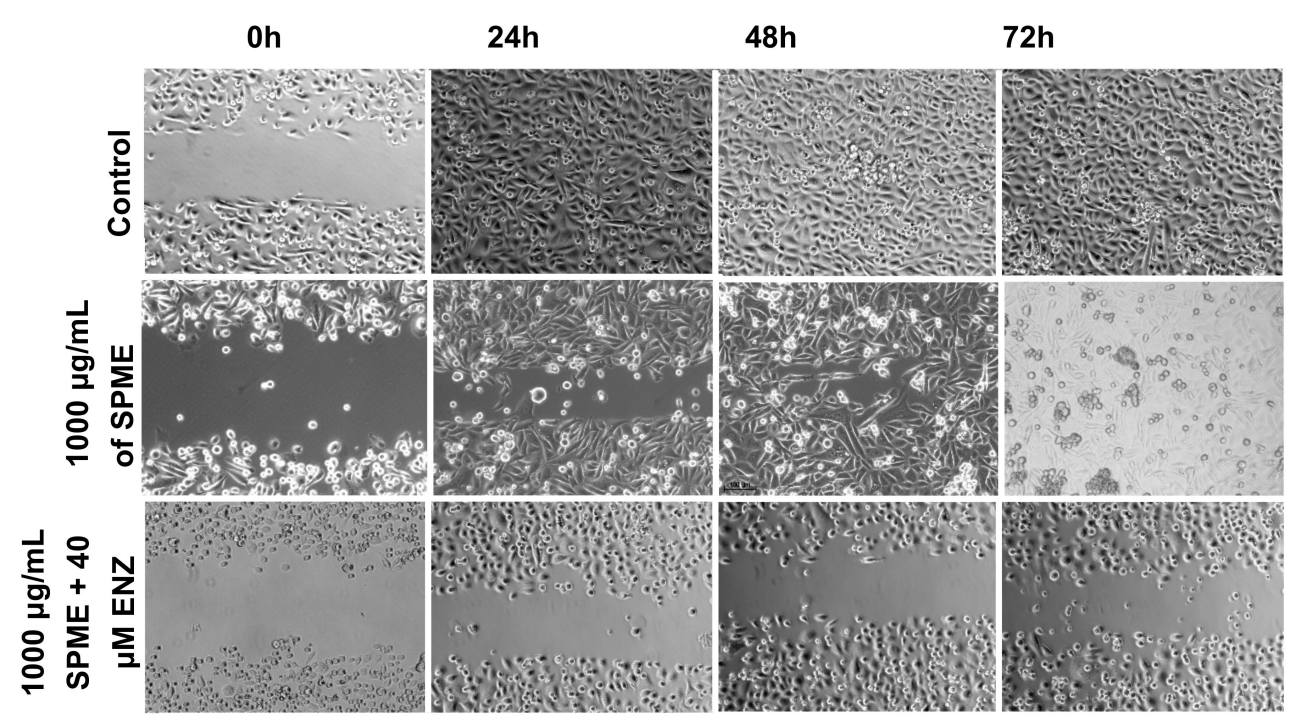

\section{SPME and enzalutamide on PC-3 migration}
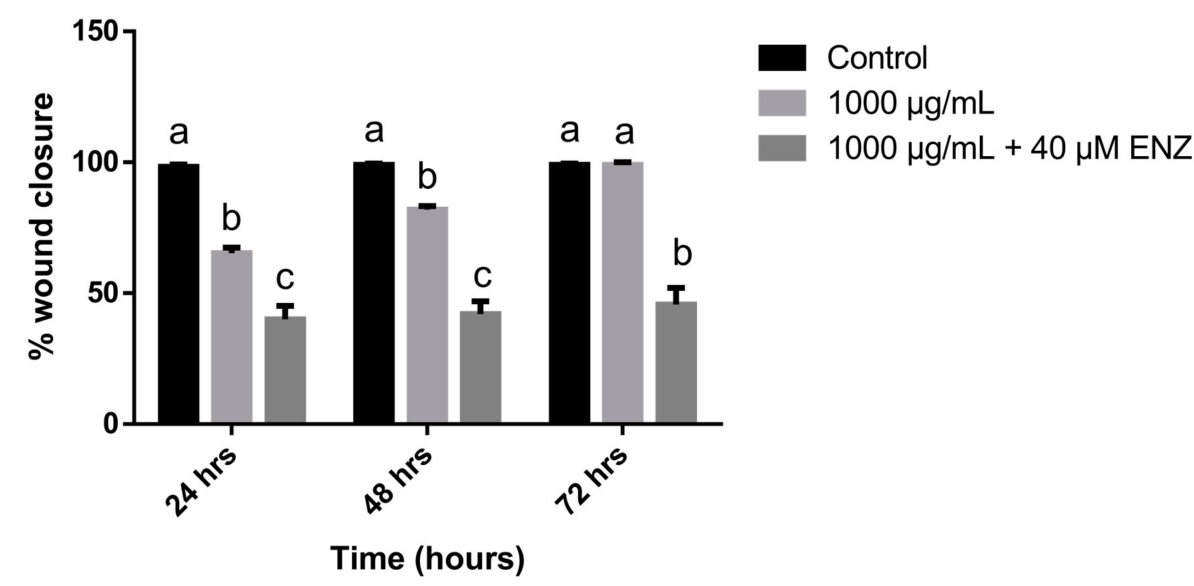

Figure 8. Effect of SPME in combination with enzalutamide on PC-3 cell migration. Micrography and statistical analysis of the wound healing assay. Values are expressed as mean \pm S.E.M. Values with different letters $(\mathrm{a}-\mathrm{c})$ are significantly different $(P<0.05)$. Experiments were performed three times. 


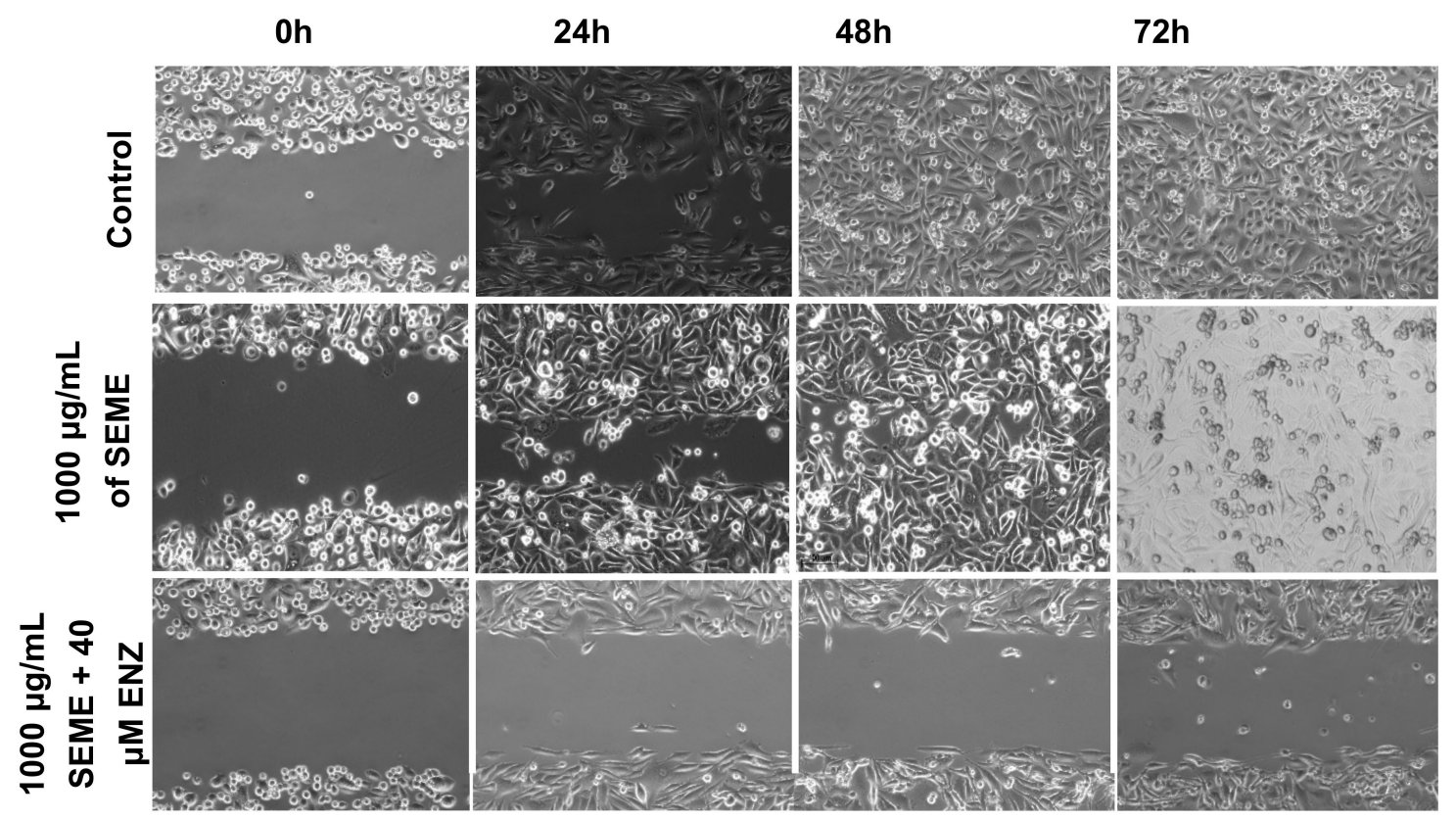

SEME and enzalutamide on PC-3 migration

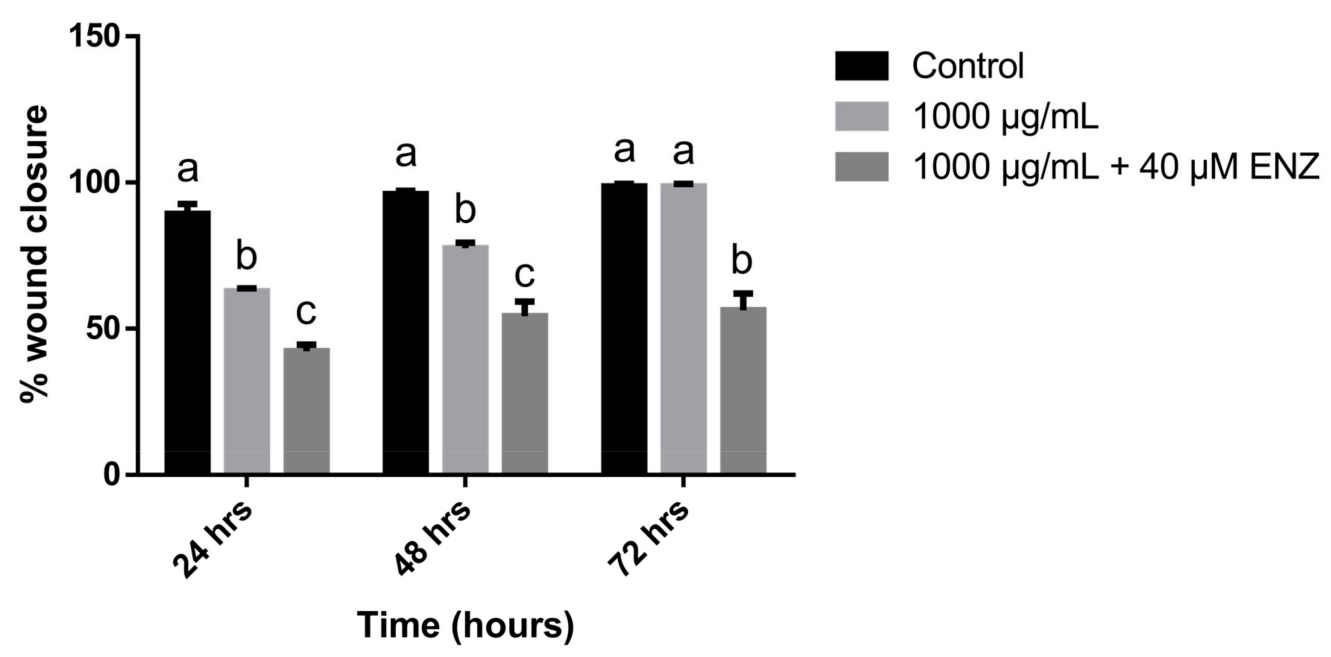

Figure 9. Effect of SEME in combination with enzalutamide on PC-3 cell migration. Micrography and statistical analysis of the wound-healing assay. Values are expressed as mean \pm S.E.M. Values with different letters $(\mathrm{a}-\mathrm{c})$ are significantly different $(P<0.05)$. Experiments were performed at least three times.

\section{Discussion}

The results showed that both SPME and SEME have no cytotoxic effect on human fibroblastic cells at concentrations ranging from 250 to $1000 \mu \mathrm{g} / \mathrm{mL}$, and these results are consistent with the report on peripheral blood mononuclear cells exposed to Stevia rebaudiana extract [15]. In this project, the Stevia extracts were able to reduce the viability of the LNCaP and PC-3 cancer cells at all concentrations evaluated, and this effect is similar to that observed for Stevia rebaudiana extracts in breast cancer (MCF-7 and MDA), colon cancer (Caco2 and HCT116), lung cancer (A-549), cervical cancer (He-La), and pancreatic cancer cells (MiaPaCa-2) $[10,16]$. There are no previous reports on Stevia pilosa and Stevia eupatoria and their effects on cancer cells. However, their chemical composition has been reported, which helped us to explain their effects. Stevia pilosa and Stevia eupatoria extracts have compounds 
such as luteolin, quercetin, $\beta$-sitosterol, stigmasterol [11], seco-triterpenes [17], and longipinenes [18]. Luteolin has shown cellular arrest and apoptosis induction in many types of cancer cell lines, such as prostate cancer (PC-3), liver cancer (SMMC7721), colon cancer (COLO205), and cervical cancer (HeLa) [19]. Quercetin decreases the viability and proliferation of MCF-7 breast cancer cells through apoptosis activation, via increasing the levels of Bcl-2-associated $X$ protein (BAX) and caspase- 3 expression and decreasing Bcl-2 expression. In addition, quercetin activates necroptosis, via increasing the levels of receptor-interacting serine/threonine-protein kinase 1 (RIPK1) and receptor-interacting serine/threonine-protein kinase 3 (RIPK3) expression [20,21]. Both luteolin and quercetin were tested in prostate cancer cells DU145, showing cell cycle arrest [21]. Other compounds of Stevia pilosa and Stevia eupatoria include $\beta$-sitosterol and stigmasterol, which have an antiproliferative effect by activating the extracellular receptor kinase (ERK) 1/2 pathway, and apoptosis induction, decreasing Bcl-2 expression and increasing BAX expression in breast cancer cells MDA-MB-231 [22]. Additionally, some triterpenes demonstrated cytotoxicity in several cells such as colon and stomach cancer cells, inducing apoptosis via extrinsic and intrinsic pathways and activating caspase-8, -9, and -3 [23], and HEp-2, HCT 116, MCF-7, A-549, and PC-3 cancer cells [24]. Fraction compounds, mainly obtained by pinenes, showed a cytotoxic effect in A2058, MCF-7, HL-60, and HeLa cancer cells lines [25]. Some longipinene derivates displayed cytotoxicity on lung carcinoma H1299 cells [26]. No additive effect was observed with the combination of Stevia extracts and enzalutamide. This could be because enzalutamide has a mechanism of action both on the androgen receptor pathway and on caspase- 8 and caspase-3 activation [22]. In LNCaP prostate cancer cells, enzalutamide shows overexpression in caspase- 8 and caspase-3, such as luteolin, quercetin, stigmasterol, and $\beta$-sitosterol [27]. Therefore, we suggest that the effect on cell apoptosis did not increase with the combination because competition could have occurred between the compounds rather than an addition of effects by different mechanisms; however, more studies are needed to verify this hypothesis.

No studies of the effect of Stevia on the migration of cancer cells have been conducted; however, studies have examined the compounds found in this genus. Awad et al. found that $\beta$-sitosterol decreases invasion of PC-3 prostate cancer cells in vitro. A reduction of metastases to lymph nodes and to the lungs was observed, although the pathways through which phytosterol creates this effect were not analyzed [28]. Previous work showed that luteolin has an effect on metalloproteinases (MMPs), which are necessary for the degradation of the basement membrane, thus allowing invasion and migration to secondary sites. Luteolin in glioblastoma cell lines U251MG and U87MG decreases levels of MMP-2 and MMP-9 protein. In addition, luteolin has an effect on epithelial-mesenchymal transition (EMT), decreasing the protein expression of mesenchymal markers such as N-cadherin, Vimentin, and $\beta$-catenin, and increasing the protein expression of E-cadherin, which participates in cell-cell adhesion [29-31]. Quercetin is able to reduce the migration and invasion of human skin melanoma cells SK-MEL-28, increasing the expression of epithelial markers and decreasing mesenchymal markers [32]. The combination of Stevia pilosa and Stevia eupatoria with enzalutamide did not induce an antagonist effect on the migration of cells, which is consistent with wound-healing assay with enzalutamide alone reported by Khurana, et al. [33], and different from the antagonist effect reported by the same group with enzalutamide and sulforaphane in resistant cells [34]. Based on the above, we suggest that the extracts could affect some of these mechanisms, however, additional studies are needed.

\section{Conclusions}

The results indicated that SPME and SEME have an inhibitory effect on the viability and migration in prostate cancer cells, and although there is no evidence of the extracts increasing the anti-migratory effect of enzalutamide, the data suggest that Stevia extracts may represent a potential source of molecules for the treatment of cancer.

Author Contributions: Conceptualization, E.M.-R. and J.E.-C.; Data curation, L.C.B.; Formal analysis, L.C.B.; Funding acquisition, J.E.-C.; Investigation, E.M.-R.; Methodology, E.M.-R. and R.C.-C.; Supervision, J.E.-C.; 
Visualization, G.G.-A.; Writing-Original draft, E.M.-R. and J.E.-C.; Writing-Review \& editing, R.C.-C., L.C.B., G.G.-A. and J.E.-C. All authors have read and agreed to the published version of the manuscript.

Funding: This research was funded by Apoyo a Nuevos Profesores de Tiempo Completo del Programa para el Desarrollo Profesional Docente (PRODEP) 2018, [Grant 120218].

Acknowledgments: Human fibroblasts were kindly provided by Claudia Lucia Vargas Requena (Biotechnology Lab, Universidad Autónoma de Ciudad Juárez) and LNCaP cells were provided by Brenda Anguiano (Instituto de Neurobiología, Universidad Nacional Autónoma de México). We would like to express our deep appreciation for these contributions.

Conflicts of Interest: The authors declare no conflict of interest. The sponsors had no role in the design, execution, interpretation, or writing of the study.

\section{References}

1. Mattiuzzi, C.; Lippi, G. Current Cancer Epidemiology. J. Epidemiol. Glob Health 2019, 9, 217-222. [CrossRef] [PubMed]

2. Pernar, C.H.; Ebot, E.M.; Wilson, K.M.; Mucci, L.A. The Epidemiology of Prostate Cancer. Cold Spring Harb. Perspect. Med. 2018, 8, a030361. [CrossRef] [PubMed]

3. Shafi, A.A.; Yen, A.E.; Weigel, N.L. Androgen receptors in hormone-dependent and castration-resistant prostate cancer. Pharmacol. Ther. 2013, 140, 223-238. [CrossRef] [PubMed]

4. Schatten, H. Brief Overview of Prostate Cancer Statistics, Grading, Diagnosis and Treatment Strategies. Adv. Exp. Med. Biol. 2018, 1095, 1-14. [CrossRef]

5. Lonergan, P.E.; Tindall, D.J. Androgen receptor signaling in prostate cancer development and progression. J. Carcinog. 2011, 10, 20-34. [CrossRef]

6. Sanford, M. Enzalutamide: A review of its use in metastatic, castration-resistant prostate cancer. Drugs 2013, 73, 1723-1732. [CrossRef]

7. Ito, Y.; Sadar, M.D. Enzalutamide and blocking androgen receptor in advanced prostate cancer: Lessons learnt from the history of drug development of antiandrogens. Res. Rep. Urol. 2018, 10, 23-32. [CrossRef]

8. Tombal, B.; Saad, F.; Penson, D.; Hussain, M.; Sternberg, C.N.; Morlock, R.; Ramaswamy, K.; Ivanescu, C.; Attard, G. Patient-reported outcomes following enzalutamide or placebo in men with non-metastatic, castration-resistant prostate cancer (PROSPER): A multicenter, randomised, double-blind, phase 3 trial. Lancet Oncol. 2019, 20, 556-569. [CrossRef]

9. Haque, M.A.; Islam, M.; UI, A. Pleurotus highking Mushroom Induces Apoptosis by Altering the Balance of Proapoptotic and Antiapoptotic Genes in Breast Cancer Cells and Inhibits Tumor Sphere Formation. Medicina 2019, 55, 716. [CrossRef]

10. López, V.; Pérez, S.; Vinuesa, A.; Zorzetto, C.; Aban, O. Stevia rebaudiana ethanolic extract exerts better antioxidant properties and antiproliferative effects in tumour cells tan its diterpene glycoside stevioside. Food Funct. 2016, 7, 2107-2113. [CrossRef]

11. Cariño-Cortés, R.; Hernández-Ceruelos, A.; Torres-Valencia, J.M.; González-Avila, M.; Arriaga-Alba, M.; Madrigal-Bujaidar, E. Antimutagenicity of Stevia pilosa y Stevia eupatoria evaluated with the Ames test. Toxicol. In Vitro 2007, 21, 691-697. [CrossRef] [PubMed]

12. Cerda-García-Rojas, C.M.; Pereda-Miranda, R. The Genus Stevia. In The Phytochemistry of Stevia: A General Survey; Taylor \& Francis: New York, NY, USA, 2002; Chapter 5; pp. 86-118.

13. Khare, N.; Chandra, S. Stevioside mediated chemosensitization studies and cytotoxicity assay on breast cancer cell lines MDA-MB-231 and SKBR3. Saudi J. Biol. Sci. 2019, 26, 1596-1601. [CrossRef] [PubMed]

14. Mann, T.S.; Agnihotri, V.K.; Kumar, D.; Pal, P.K.; Koundal, R.; Kumar, A.; Padwad, Y.S. In vitro cytotoxic activity guided essential oil composition of flowering twigs of Stevia rebaudiana. Nat. Prod. Commun. 2014, 9, 715-718. [CrossRef] [PubMed]

15. Panagiotou, C.; Mihailidou, C.; Brauhli, G.; Katsarou, O.; Moutsatsou, P. Effect of steviol, steviol glycosides and stevia extract on glucocorticoid receptor signaling in normal and cancer blood cells. Mol. Cell Endocrinol. 2017, 460, 189-199. [CrossRef] [PubMed]

16. Vaško, L.; Vašková, J.; Fejerčáková, A.; Mojžišová, G.; Poráčová, J. Comparison of some antioxidant properties of plant extracts from Origanum vulgare, Salvia officinalis, Eleutherococcus senticosus and Stevia rebaudiana. In Vitro Cell Dev. Biol. Anim. 2014, 50, 614-622. [CrossRef] [PubMed] 
17. Román, L.U.; Guerra-Ramírez, D.; Morán, G.; Martínez, I.; Hernández, J.D.; Cerda-García-Rojas, C.M.; Torres-Valencia, J.M.; Joseph-Nathan, P. First seco-oleananes from nature. Org. Lett. 2004, 6, 173-176. [CrossRef]

18. Alvarez-García, R.; Torres-Valencia, J.M.; Román, L.U.; Hernández, J.D.; Cerda-García-Rojas, C.M.; Joseph-Nathan, P. Absolute configuration of the alpha-methylbutyryl residue in longipinene derivatives from Stevia pilosa. Phytochemistry 2005, 66, 639-642. [CrossRef]

19. Lu, X.; Li, Y.; Li, X.; Aisa, H.A. Luteolin induces apoptosis in vitro through suppressing the MAPK and PI3K signaling pathways in gastric cancer. Oncol. Lett. 2017, 14, 1993-2000. [CrossRef]

20. Khorsandi, L.; Orazizadeh, M.; Niazvnd, F.; Abbaspour, M.R.; Mansouri, E.; Khodadadi, A. Quercetin induces apoptosis and necroptosis in MCF-7 breast cancer cells. Bratisl. Lek. Listy 2017, 118, 123-128. [CrossRef]

21. Zhang, Q.; Cheng, G.; Qiu, H.; Wang, Y.; Wang, J.; Xu, H.; Zhang, T.; Liu, L.; Tao, Y.; Ren, Z. Expression of prostate stem cell antigen is downregulated during flavonoid-induced cytotoxicity in prostate cancer cells. Exp. Ther. Med. 2017, 14, 1795-1801. [CrossRef]

22. Awad, A.B.; Fink, C.S. Phytosterols as anticancer dietary components: Evidence and mechanism of action. J. Nutr. 2000, 130, 2127-2130. [CrossRef] [PubMed]

23. Szoka, Ł.; Isidorov, V.; Nazaruk, J.; Stocki, M.; Siergiejczyk, L. Cytotoxicity of Triterpene Seco-Acids from Betula pubescens Buds. Molecules 2019, 24, 4060. [CrossRef] [PubMed]

24. Tolmacheva, I.A.; Nazarov, A.V.; Eroshenko, D.V.; Grishko, V.V. Synthesis, cytotoxic evaluation, and molecular docking studies of the semi-synthetic "triterpenoid-steroid" hybrids. Steroids 2018, 140, 131-143. [CrossRef] [PubMed]

25. Santana, J.S.; Sartorelli, P.; Guadagnin, R.C.; Matsuo, A.L.; Figueiredo, C.R.; Soares, M.G.; da Silva, A.M.; Lago, J.H. Essential oils from Schinus terebinthifolius leaves-Chemical composition and in vitro cytotoxicity evaluation. Pharm. Biol. 2012, 50, 1248-1253. [CrossRef]

26. Cerda-García-Rojas, C.M.; Burgueño-Tapia, E.; Román-Marín, L.U.; Hernández-Hernández, J.D.; Agulló-Ortuño, T.; González-Coloma, A.; Joseph-Nathan, P. Antifeedant and cytotoxic activity of longipinane derivatives. Planta Med. 2010, 76, 297-302. [CrossRef]

27. Pilling, A.B.; Hwang, O.; Boudreault, A.; Laurent, A.; Hwang, C. IAP Antagonists Enhance Apoptotic Response to Enzalutamide in Castration-Resistant Prostate Cancer Cells via Autocrine TNF- $\alpha$ Signaling. Prostate 2017, 7, 823-934. [CrossRef]

28. Awad, A.B.; Fink, C.S.; William, H.; Kim, U. In vitro and In vivo (SCID mice) effects of phytosterols on the growth and dissemination of human prostate cancer PC-3 cells. Eur. J. Cancer Prev. 2001, 10, 507-513. [CrossRef]

29. Woyengo, T.A.; Ramprasath, V.R.; Jones, P.J.H. Anticancer effects of phytosterols. Eur. J. Clin. Nutr. 2009, 63, 813-820. [CrossRef]

30. Vundru, S.S.; Kale, R.K.; Singh, R.P. $\beta$-sitosterol induces G1 arrest and causes depolarization of mitochondrial membrane potential in breast carcinoma MDA-MB-231 cells. BMC Complement. Altern. Med. 2013, 13, 280-289. [CrossRef]

31. Wang, Q.; Wang, H.; Jia, Y.; Ding, H.; Zhang, L.; Pan, H. Luteolin reduces migration of human glioblastoma cell lines via inhibition of the p-IGF-1R/PI3K/AKT/mTOR signaling pathway. Oncol. Lett. 2015, 14, 3545-3551. [CrossRef]

32. Patel, D.H.; Sharma, N. Inhibitory effect of quercetin on epithelial to mesenchymal transition in SK-MEL-28 human melanoma cells defined by in vitro analysis on 3D collagen gels. Onco Targets Ther. 2016, 9, 6445-6459. [CrossRef] [PubMed]

33. Khurana, N.; Chandra, P.K.; Kim, H.; Abdel-Mageed, A.B.; Mondal, D.; Sikka, S.C. Bardoxolone-Methyl (CDDO-Me) Suppresses Androgen Receptor and Its Splice-Variant AR-V7 and Enhances Efficacy of Enzalutamide in Prostate Cancer Cells. Antioxidants (Basel) 2020, 9, 68. [CrossRef] [PubMed]

34. Khurana, N.; Talwar, S.; Chandra, P.K.; Sharma, P.; Abdel-Mageed, A.B.; Mondal, D.; Sikka, S.C. Sulforaphane increases the efficacy of anti-androgens by rapidly decreasing androgen receptor levels in prostate cancer cells. Int. J. Oncol. 2016, 49, 1609-1619. [CrossRef] [PubMed]

(C) 2020 by the authors. Licensee MDPI, Basel, Switzerland. This article is an open access article distributed under the terms and conditions of the Creative Commons Attribution (CC BY) license (http://creativecommons.org/licenses/by/4.0/). 